\title{
The selection of the engine unit - main engine generator during the modernization of the 19D/TEM2 locomotive
}

The paper aims to present a generating set selection methodology for a modernized diesel locomotive. An analysis of the number of rolling stock, with particular emphasis on the number of diesel locomotives owned by national carriers was performed. Based on the popularity of the locomotives operated on Polish railways, the TEM2 locomotive was chosen to be the base reference for the modernized $19 D$ locomotive described in the paper. The scope of the locomotive's modernization was described. Modernization included: replacement of the internal combustion engine, replacement of the generator set, installation of a new braking system with a pneumatic board and air preparation and treatment system, application of a modern control and diagnostics system with anti-slip system at start-up and braking, and the installation of railway traffic safety devices.

Key words: railway, diesel locomotive, modernization, CFD simulation, exhaust emission

\section{Introduction}

Road transport is not the only branch of transport subject to strict restrictions, whereby it is required to meet said restrictions in tests performed to estimate the environmental impact of vehicles [4, 24]. The legal regulations in force [8] and the exhaust emission norms [7] force carriers to invest in improving the technical condition, reducing the environmental impact $[5,10]$ and increasing the efficiency of vehicles in operation, including diesel locomotives. Meeting these types of requirements is possible in several ways, ranging from innovative technical solutions [2, 16, 17], the purchase of new units, renovation and repair of older units or through retrofitting in the ecological aspect [18]. One of the solutions combining economic benefits with improved technical condition of the vehicle is its modernization [11, $12,20,22]$. This type of operation can include a wide range of activities. It may consist of only single changes [14] such as replacement of the drive unit with a newer one that meets the applicable exhaust emission standards or it may include a thorough modernization of the entire vehicle.

This article describes the modernization process of the type 19D locomotive series SM48 (TEM2) (Fig. 1).

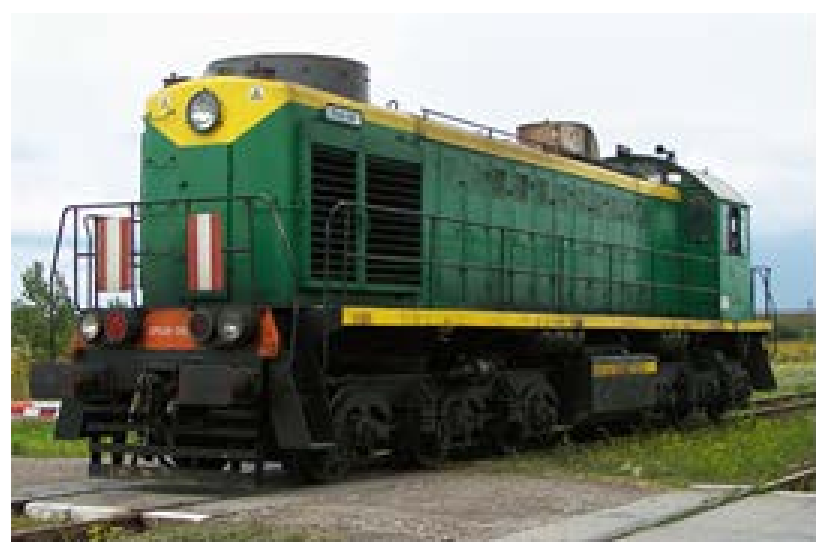

Fig. 1. The SM48 (TEM2) locomotive before modernization
The six-axle, single-cabin locomotive was constructed with the CoCo system. In the original version, it had an electric transmission and an $880 \mathrm{~kW}$ internal combustion engine. The unit was produced in the USSR and was intended for servicing the eastern border regions. It was used for heavy shunting and reloading works. After the Polish rail safety systems have been installed [6], it is also possible to use it in a freight train. Some of the manufactured units were adapted to move on tracks with a rail gauge of 1435 $\mathrm{mm}$ and $1520 \mathrm{~mm}$. Shifting to a different track is possible by replacing the wheelsets.

After thorough analyzes of the technical condition and parameters of the locomotive a decision was made to modernize the described vehicle. It was decided that a complete modernization of the vehicle would be performed. This meant replacing all the main assemblies of the locomotive. The exceptions were the frames and bogies with drive systems. After major repairs were carried out, the original technical condition of the locomotive was reached and the vehicle modernization was considered complete.

Activities related to the thorough modernization of the SM48 (TEM2) diesel locomotive included:

- Performing numerical simulations and analyzes to determine the technical and operational parameters of the main devices, machines, apparatus and generating sets that could be used in the locomotive,

- Development, manufacturing and commissioning of models of the main units and systems,

- Performing control tests of the main units and systems,

- Development of a project of vehicle fitting with devices and systems,

- Installing the necessary devices and systems in the locomotive,

- Construction and preparation of acceptance requirements and preparation of acceptance procedures,

- Development and preparation of technical documentation for the modernized locomotive,

- Performing stationary vehicle tests, 
- Performing dynamic vehicle tests,

- Preparation of legal procedures in order to obtain documented permissions for taking part in rail traffic,

- Launching the procedures related to type approval and operational tests.

\section{Polish rail market overview}

According to statistical data [1], rail transport is a dynamically developing branch of transport in Poland. Since 2010, there has been an increase in performed operational work by $17 \%$ (Fig. 2). In the case of freight transport, according to [27], the annual forecast volume dynamics of the total demand for freight transport in rail transport is to increase depending on the scenario, from $13.4 \%$ to even $25 \%$ (Fig. 3) by 2030. Even considering the most pessimistic forecast, this will translate into a significant increase in rail transport.

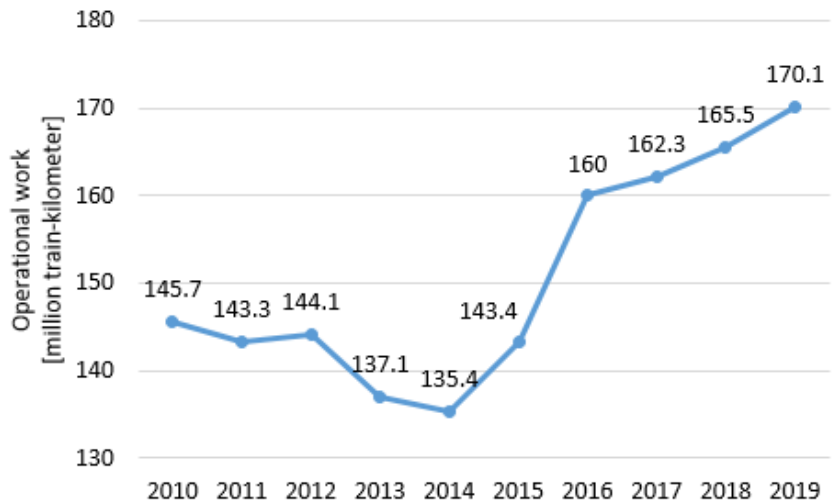

Fig. 2. Operational work in passenger rail transport in Poland in 2010-2019 (standard-gauge transport) [1]

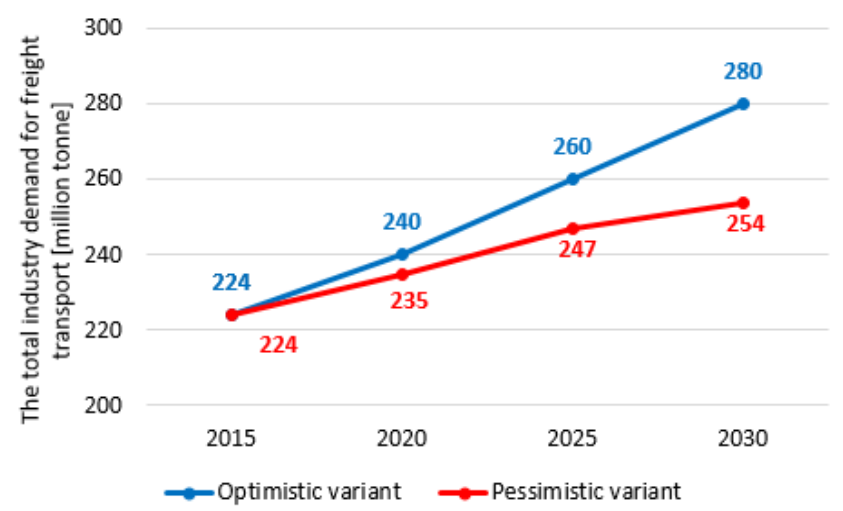

Fig. 3. The projected volume of the total industry demand for freight transport by rail in Poland (carried out by Polish and foreign carriers) [27]

The growing demand for rail transport in Poland is realized on the railway lines, whose total length is $19,235 \mathrm{~km}$ [25]. With this value, there are $6.2 \mathrm{~km}$ of railway lines per every $100 \mathrm{~km}^{2}$ of the country's land area. Presented as ratio of rail line length per 10 thousand people, this value is $5 \mathrm{~km}$. The density of the railway network in Poland is not high when compared, for example, to the situation in the neighboring country - the Czech Republic - where the same indicators are almost twice as high [13]. The electrified lines in Poland with a total length of 11,894 km constitute $62 \%$ of the total network size. However, electrification
(Fig. 4) and the density of railway lines in the country are not uniform. Especially in the areas of eastern Poland, the share of railway lines with electric traction has a low percentage. For example, in the Podlaskie Voivodeship the electric traction is only $219 \mathrm{~km}$ out of $759 \mathrm{~km}$ (29\%), in the Lubelskie Voivodeship 416/1048 km (40\%), and in the Podkarpackie Voivodeship 370/978 km (38\%) [25]. This means that only rail vehicles equipped with a drive system that can operate independent of electric traction can travel on most of the railway routes in these areas. In practice, this means locomotives and multiple units equipped with diesel engines.

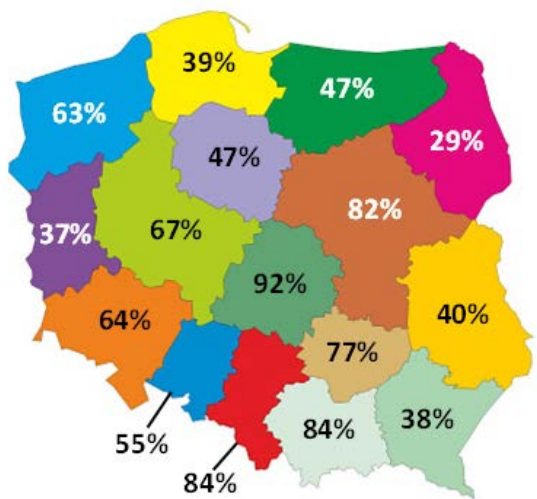

Fig. 4. Share of electrified railway lines in individual voivodships in Poland

The planned increase in the number of rail transport operations, both passenger and freight, requires carriers to have an appropriate sized rolling stock, including units that can operate fully independent of electric traction. In addition, the demand for rail transport will also increase the amount of shunting work performed mainly by rail vehicles with a diesel engine. Currently, 109 diesel passenger locomotives and 269 diesel traction units are used in passenger transport [21]. In the case of freight rolling stock in Poland, there is a constant trend of increasing use of diesel locomotives, characterized by greater operating autonomy, compared to electric locomotives [26] (Fig. 5).

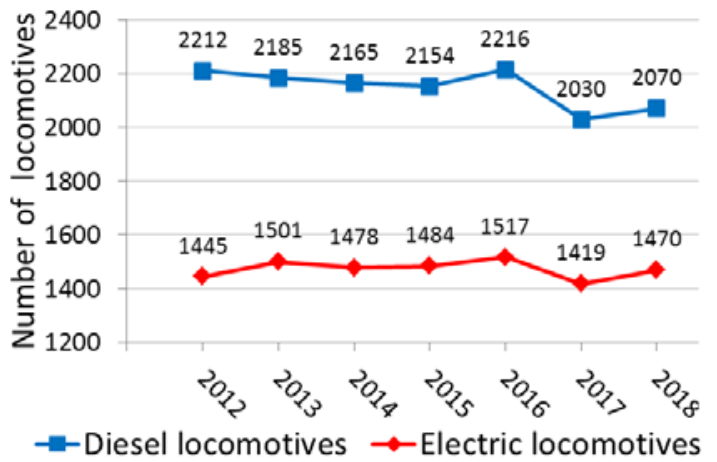

Fig. 5. Freight locomotives in Poland in the years 2012-2018

In Poland, the most frequently used rolling stock was manufactured between 1970 and 1980. This means that a large part of the locomotives were still manufactured in the times when there were no exhaust emission norms or 
when the regulations in force related to the reduction of engine exhaust emissions were very liberal. The average age of freight diesel locomotives in Poland is 36.9 years [26], and passenger diesel locomotives 41.7 years [21]. Additionally, worn-out shunting locomotives constitute a large share of diesel locomotives in the country. As a result, in 2018 over $80 \%$ of diesel locomotives were over 40 years old [15]. Due to the significant age of rail vehicles and the continuous aging process, rail carriers have been increasing the locomotive utilization index since 2016 in order to improve the efficiency of their operation and work organization (Fig. 6). These activities translated into a relative increase of the discussed indicator by 18.9\% from 2016.

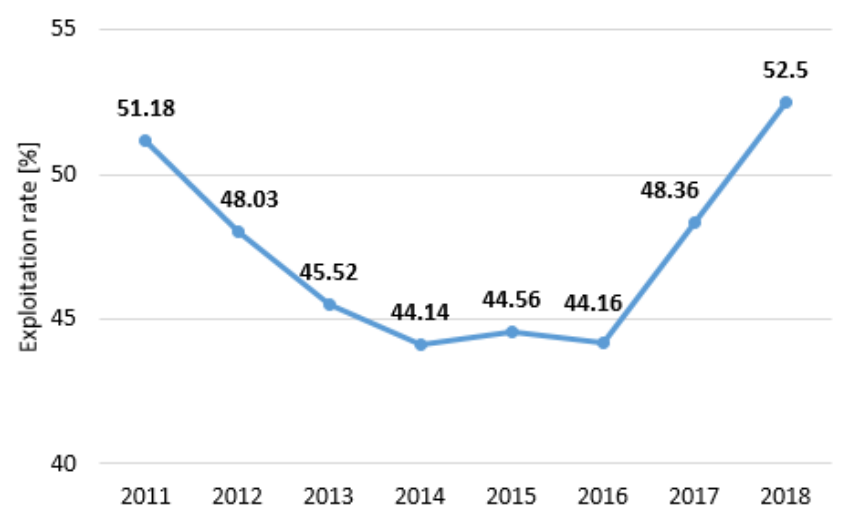

Fig. 6. The use of locomotives in Poland according to the daily quantity in years 2011-2018

A significant portion of the rolling stock in Poland is at an advanced stage of wear and tear. This situation is pointed out by the President of the Office of Rail Transport in Poland: "The figures provided show how large the scale of rolling stock investments is needed in the upcoming 10 years” [15]. For this reason, the Ministry of Infrastructure introduced the National Railway Program that is to last until 2023, which includes a number of railway investments [19]. The effects of the project include planned investments in rolling stock. By 2023, investments of approximately $€ 360$ million are expected to cover 116 electric locomotives and 168 diesel locomotives (Fig. 7). In the case of diesel locomotives, the operations are to include renovation and modernization of old vehicles, purchase of used vehicles, lease and purchase of new vehicles (Fig. 8).

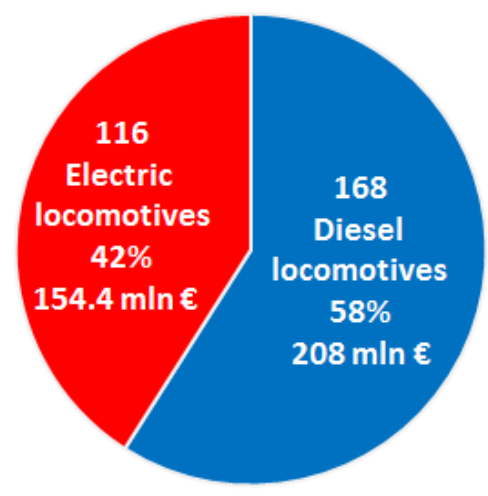

Fig. 7. Investments into diesel and electric locomotives planned for 2023 in Poland (for the group of surveyed carriers performing $80 \%$ of national transport operations)

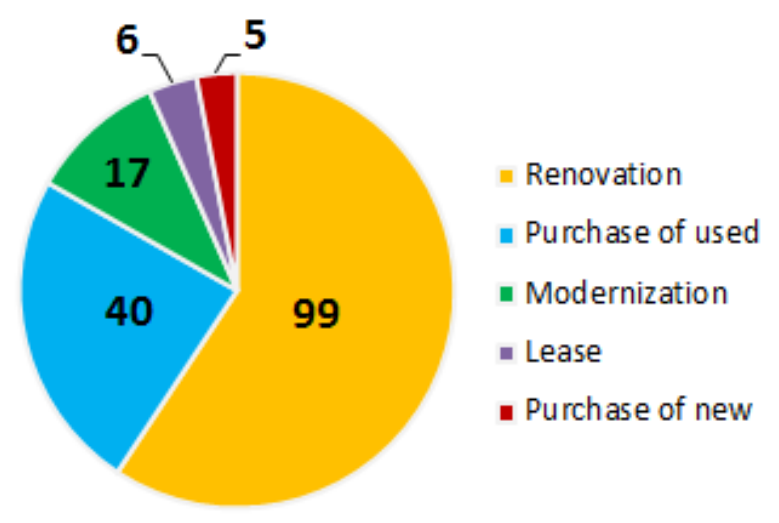

Fig. 8. Number of diesel locomotives included in the planned investments until 2023 in Poland (for the eight surveyed carriers)

\section{Locomotive modernization process}

\subsection{Extent of works}

Modernization works are a very complex processes that require vast knowledge and an experienced team of specialists and engineers from the railway sector. The TEM2 locomotive modernization project was created by the Łukasiewicz Research Network - Institute of Rail Vehicles "TABOR" in Poznań. All repair and modernization works were carried out by Pojazdy Szynowe PESA Bydgoszcz S.A.

The project included a number of activities related to the overhaul of the frames and bogies, as well as modifications that allowed for the installation of a new drive system and body. The most important of them were:

- Replacing the drive system,

- Installation of a new, autonomous driver's cab with two independent desks and seats, control cabinets, cameras facilitating operation and improving safety,

- Installation of the control and diagnostics system,

- Replacement of the pneumatic control cabinet,

- Installation of a new anti-slip system when starting and braking,

- Installation of a new air preparation and treatment system with a screw compressor driven by an electric motor,

- Installation of devices related to safety in motion and devices related to radio communication,

- Installation of electronic recorders of operating parameters and speedometers, including the ability of remote viewing of selected data,

- Modernization of the brake lever system on the bogey,

- Installation of a permanent fire control system with aerosols.

\subsection{Generator set}

One of the main goals of the modernization process was to replace the engine unit. The worn-out PD1M combustion engine manufactured in the USSR was replaced with a type 12V4000R84 MTU engine. This engine with a power of $1800 \mathrm{~kW}$ at $1800 \mathrm{rpm}$ and dimensions of $2675 \times 1700 \times 2005$ $\mathrm{mm}$, dedicated to rail transport, meets the Stage IIIB emission norms [3]. The generator set was also replaced along with the internal combustion engine - the main generator 
and the auxiliary JENOPTIK generator, and a built-in rectifier. The main generator, adapted to the specific working conditions in railway vehicles, had a rated power of 1800 $\mathrm{kW}$. The generator's operating range was between 600 and $1800 \mathrm{rpm}$. The maximum current was $6600 \mathrm{~A}$, and the maximum voltage was $750 \mathrm{~V}$. The $120 \mathrm{~kW}$ synchronous auxiliary generator with a voltage of $3 \times 450 \mathrm{~V}$ AC was directly flanged to the main generator. Figure 9 shows the generating set before and after the modernization.
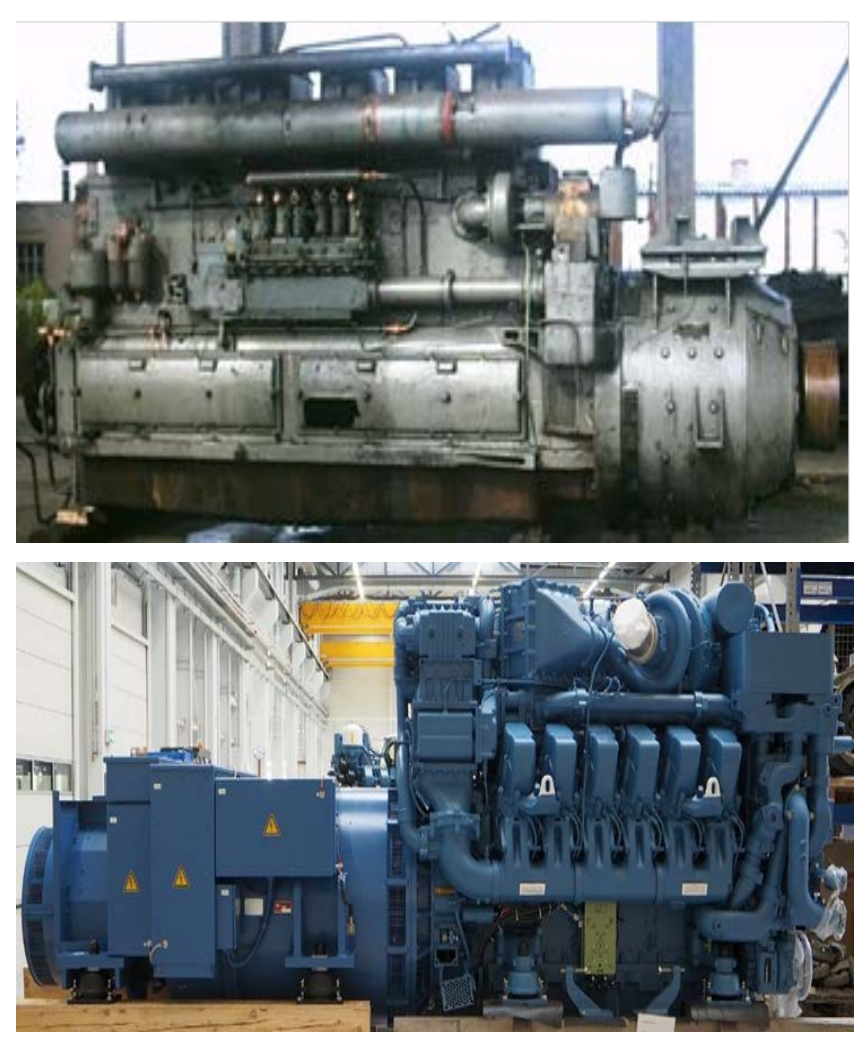

Fig. 9. View: top - generator set with engine type PD1M (before modernization) and bottom - generator set with engine type MTU 12V4000R84 (after modernization)

The process of replacing the main engine was highly complex. The installation of the internal combustion engine gave rise to many construction and design challenges that had to be completely resolved during the modernization of the locomotive. The installation of a modern engine concerned not only the main propulsion unit but also connected devices and secondary systems. Examples include the power supply system, the cooling system with the pre-heater system and the hydrostatic fan, the exhaust system with the Diesel Particle Filter (DPF), and the air intake system with its filters. The installation of the internal combustion engine also required precise data from the manufacturer on the engine attachment method to the locomotive's frame, couplings of the engine with the generator set, and mounting of the hydrostatic pump of the radiator fan drive. Data on the values of maximum negative pressures in the fuel systems and air consumption in various operating conditions were also required. The MTU 12V4000R84 internal combustion engine attached to the frame with peripheral devices is shown in Fig. 10.

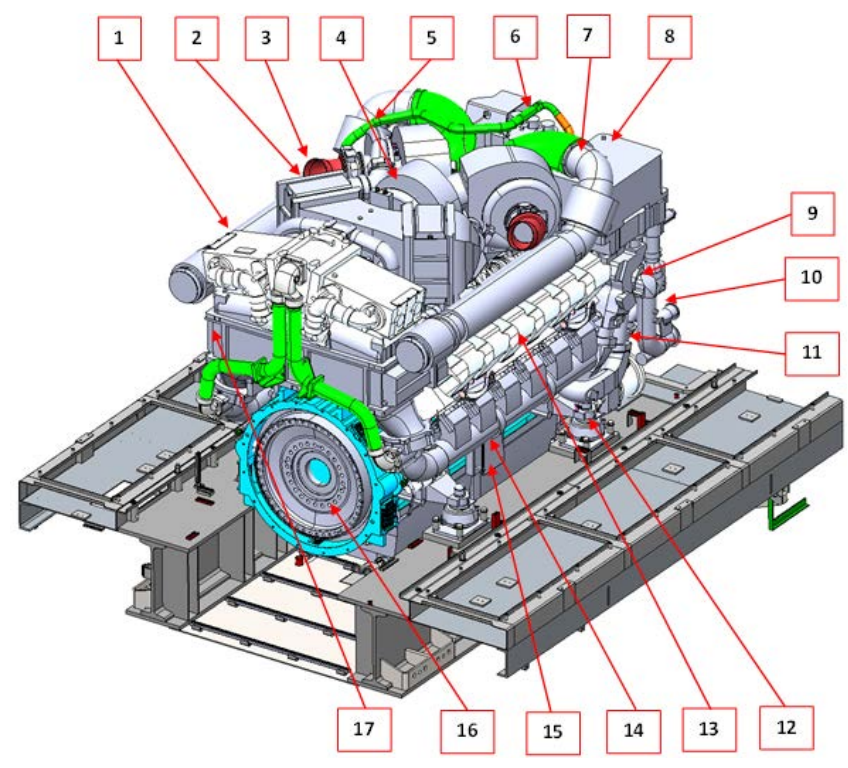

Fig. 10. MTU 12V4000R84 combustion engine, where: 1 - exhaust gas recirculation cooler (EGR cooler), 2 - charge air cooler (high temperature), 3 - air inlet, 4 - exhaust gas driven turbocharger (high pressure), 5 exhaust gas driven turbocharger (low pressure), 6 - venting crankcase, 7 exhaust outlet, 8 - oil heat exchanger, 9 - engine coolant inlet, 10 - charge air coolant outlet, 11 - coolant pumps (LT/HT), 12 - elastic support, 13 cylinder head, 14 - starter control module (POM), 15 - engine oil sump, 16 - power receiver on the drive side, 17 - charge air cooler (low temperature)

\subsection{Selection of the intake duct}

The constructors' task was to meet the requirements specified by the manufacturer. Verification of the correct operation of individual systems was also possible thanks to simulations and computer analyzes. They ensure the correct speed of operation and eliminate the need to carry out some of the time-consuming and costly bench and dynamic tests.

An example of how analyzes and computer simulations can be used in the design phase of the modernized locomotive were CFD (Computational Fluid Dynamics) simulations of air intake necessary for the combustion process. The installation of the new internal combustion engine required the design of an air intake duct to have an optimal shape that connects the engine turbocharger with air filters. The duct had to have a sufficiently low level of flow resistance, which was to make it easier to cover the air demand. The turbocharger is able to take the required amount of air into the inlet channel with a new filter installed only for pressure drops not greater than $2500 \mathrm{~Pa}$. In the case of a dirty filter, the pressure drops may not exceed $3500 \mathrm{~Pa}$. The new air filter generates a pressure drop of $1000 \mathrm{~Pa}$ for the air flow of $1.1 \mathrm{~m}^{3} / \mathrm{s}$. Therefore, the airflow through the duct with the new filter can operate correctly with a pressure drop of $1500 \mathrm{~Pa}$ in the inlet ducts. Due to the lack of space when installing the engine, it was necessary to use a strong bend of the inlet channel with a radius of $200 \mathrm{~mm}$. The inlet conduit at the bend was a flexible hose with a length of $500 \mathrm{~mm}$. According to the manufacturer's specification, the pipe had a smooth surface, therefore, for simulation purposes, it was decided to model this element as a steel pipe.

Three configurations of the inlet channel were created and labelled: A, B and C. Numerical models 1, their divi- 
A
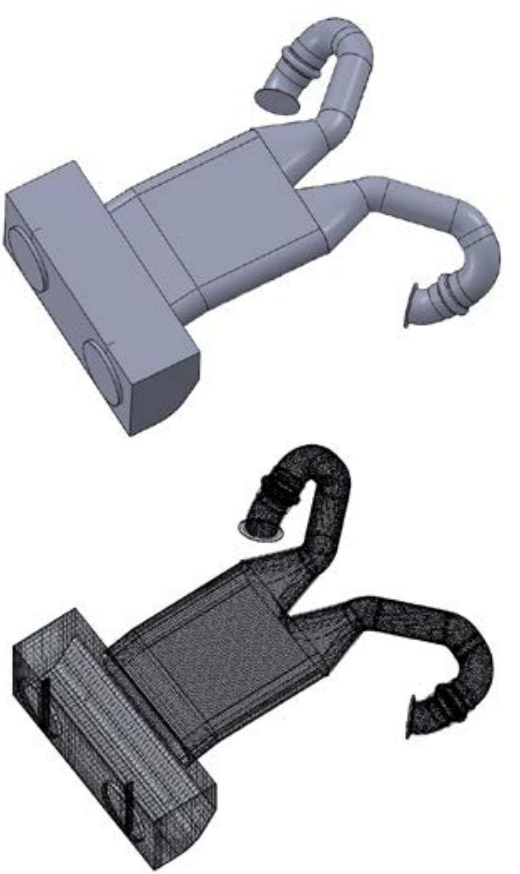

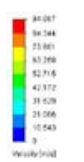

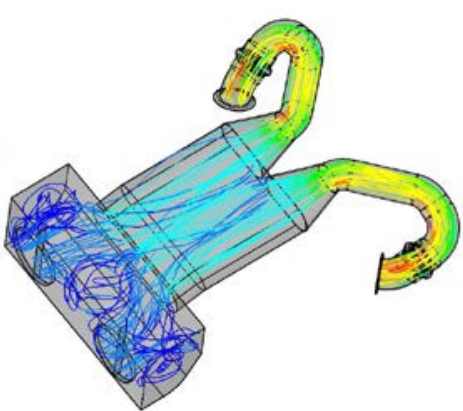

C
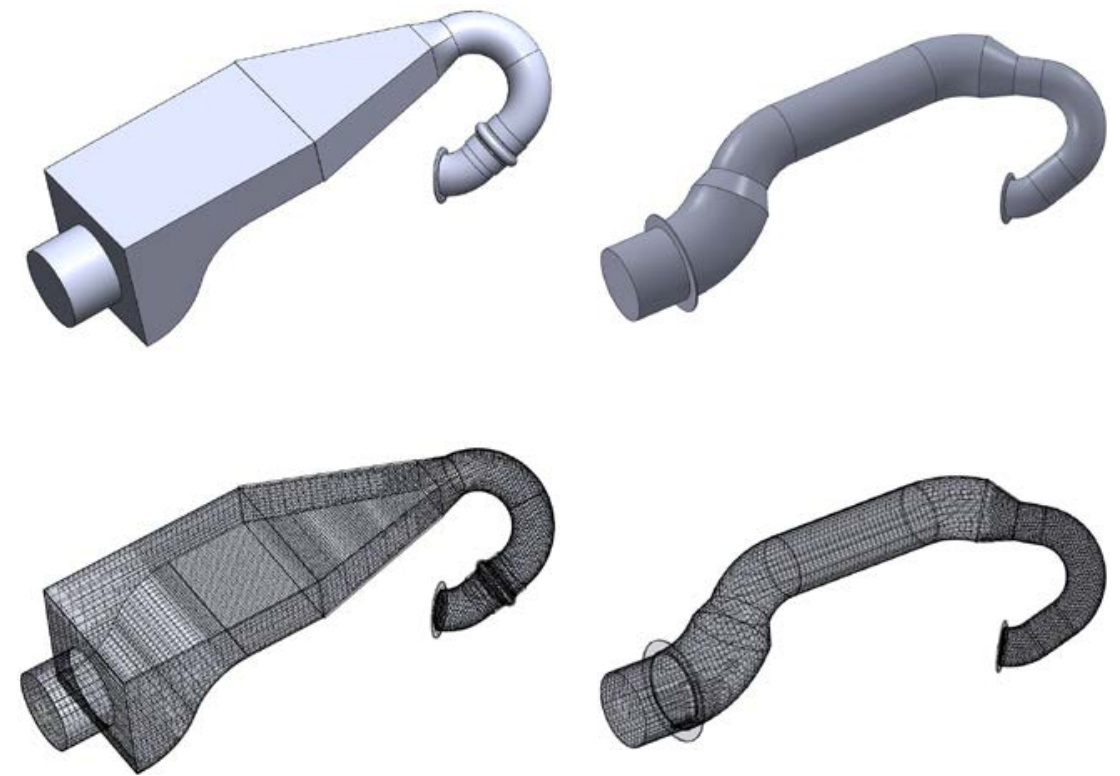

I
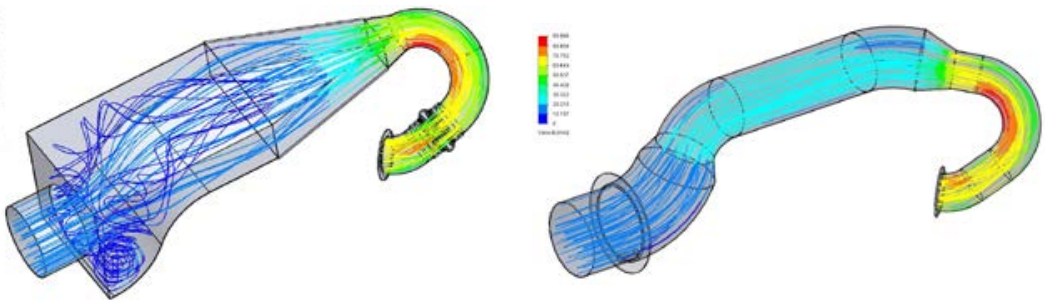

Fig. 11. CFD simulations of the intake systems in configurations A, B, and C of the 19D locomotive: 1 - numerical models, 2 - division of numerical models into finite elements, 3 - distribution of air velocity

sion into finite elements 2 and the flow velocity distribution 3 in the described systems were shown in Fig. 11. Due to the software requirements, the inlets and outlets of the tested parts were closed. An atmospheric pressure of 1013.25 hPa was applied to each air inlet to the system. At the outlet of the system, the value of the air volume flow required to be delivered to the turbocharger was set at $1.1 \mathrm{~m}^{3} / \mathrm{s}$.

The flow resistance values occurring in the inlet channels for a given configuration were obtained through the performed simulations. The highest flow resistance was observed in the system A - $2028 \mathrm{~Pa}$. System B generated a loss of $1122 \mathrm{~Pa}$ in the intake channel. The smallest values of flow resistance occurred in configuration $\mathrm{C}-522 \mathrm{~Pa}$. The permissible pressure drop level of the air stream going into the turbocharger, which was $1500 \mathrm{~Pa}$, was met by the $\mathrm{B}$ and $\mathrm{C}$ systems. The $\mathrm{C}$ system turned out to be the most advantageous configuration. Thanks to the laminar flow of the air stream and the use of an elastic duct with a constant cross section the generated flow resistance values were the smallest in the system $\mathrm{C}$, despite having a more complex shape than system B. In addition, system $C$ takes up much less space, which facilitates servicing and maintenance actions thanks to the ease of access to other engine components.

\section{Results of modernization}

After modernization the SM48 (TEM2) locomotive was designated as 19D. The new design adopted a modular structure for the locomotive. Thus, the vehicle has been built into block sections that could be mounted independenlty. The design was divided into: refrigerationcompressor, generator set, driver's cab, and electropneumatic (Fig. 12) compartments. The internal combustion engine with the generator - the generator set compartment - were installed on the underframe. The compressor set, the traction cabinet and fans of the traction motors were also attached to the body frame. The remaining sections were made so that they could be lifted with an overhead crane during service and maintenance work. In addition, the modules were equipped with flaps, multi-wing doors and removable roofs to facilitate access and accelerate the replacement of damaged elements. Figure 13 shows the arangement of the main devices in the locomotive. The modular construction of the locomotive allowed for the acceleration of design and production works, and also allowed for the efficient preparation of construction and technical documentation. 


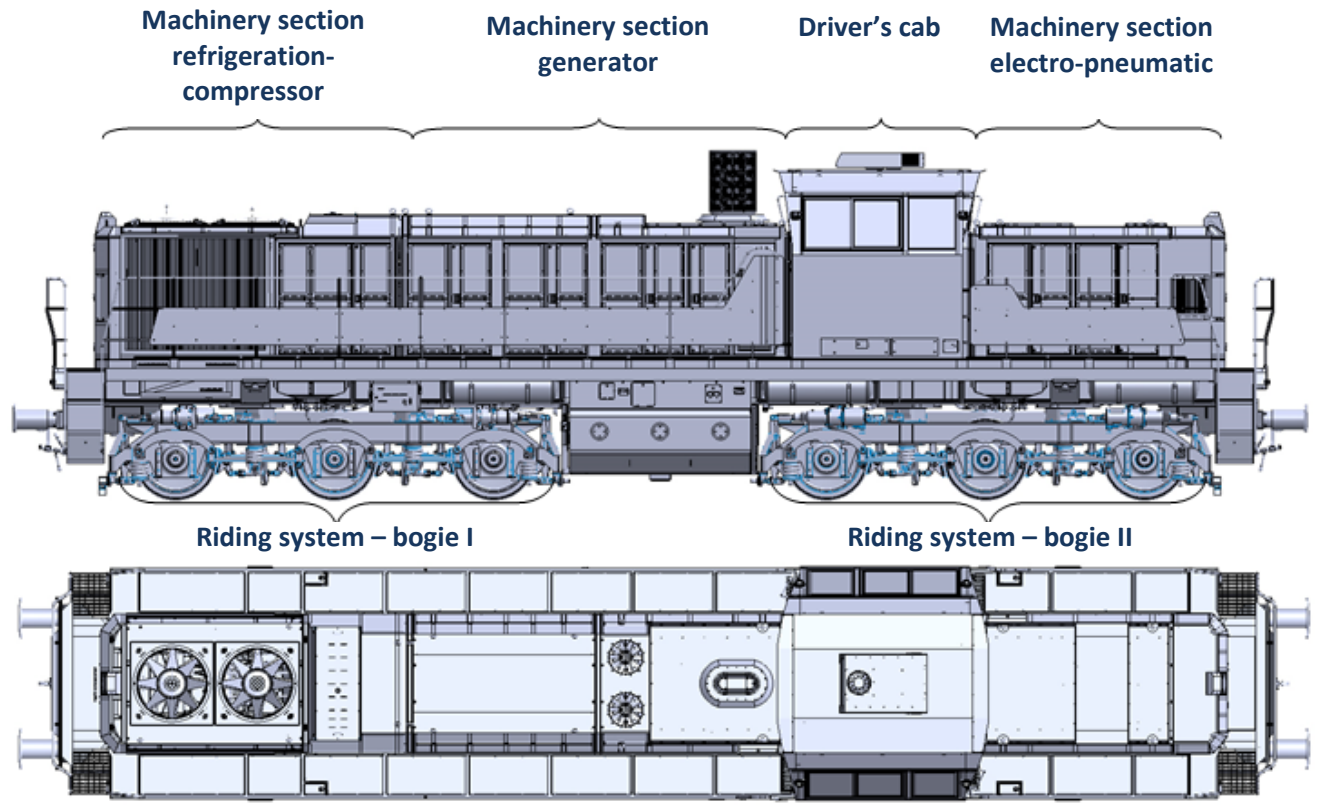

Fig. 12. Arrangement of the main compartments on the 19D locomotive (left and top view)

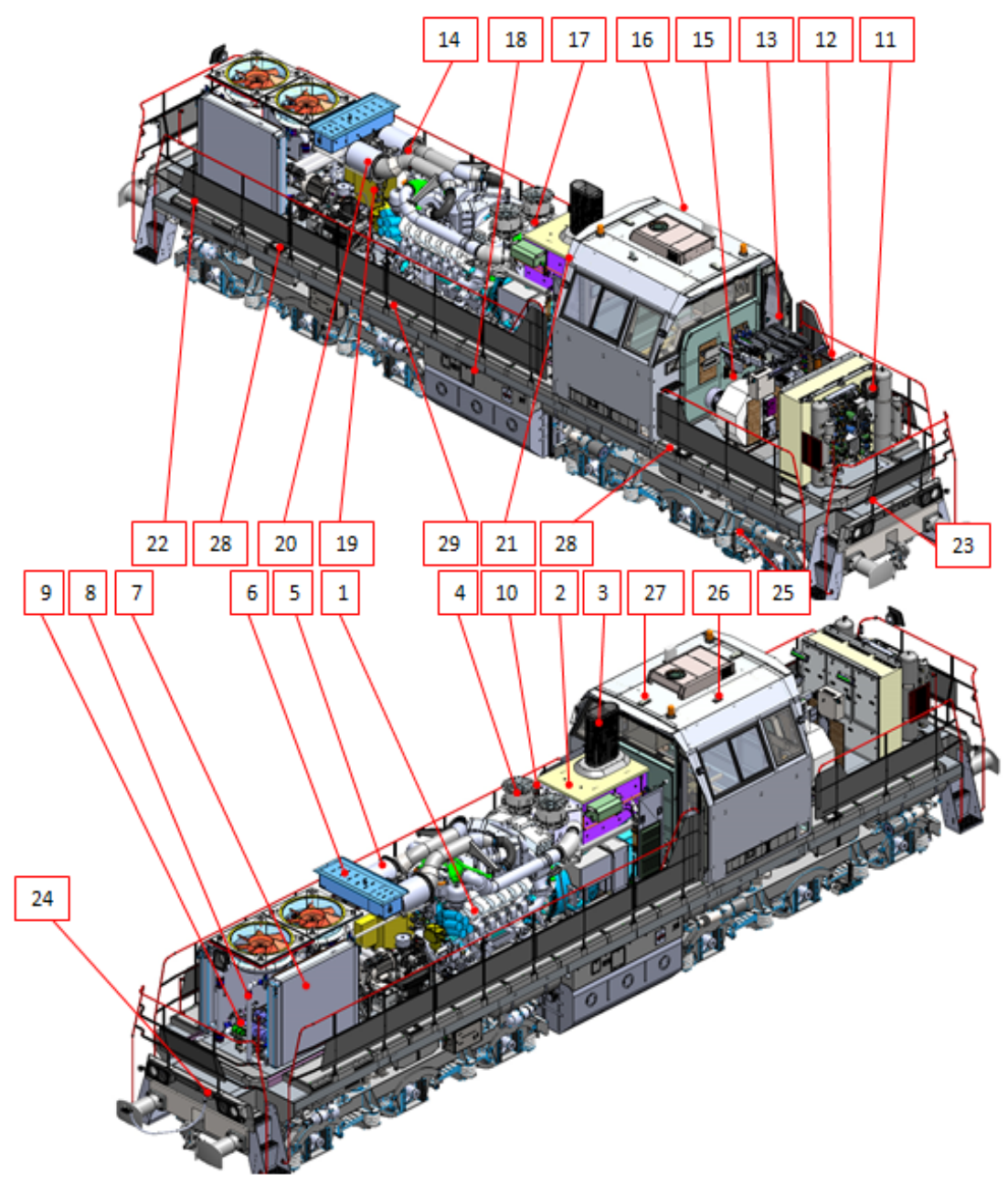

1. generator with MTU combustion engine,

2. exhaust muffler with a particulate filter,

3. exhaust outlet pipe,

4. fans of the machinery section - power generator,

5. air intake system for the combustion engine with air filters,

6. regulation tank of the internal combustion engine cooling system,

7. cooler system,

8. fans of the combustion engine cooling system,

9. WEBASTO water heaters,

10. REBS system for wheel flange lubrication,

11. pneumatic board and auxiliary air tanks,

12. JENOPTIK converter cabinet,

13. devices of the MV and LV cabinets,

14. fan of traction motors - bogey I,

15. fan of traction motors - bogey II,

16. driver's cabin air conditioner - cooler,

17. water basin water tank,

18. fuel tank,

19. fuel pre-filter,

20. air compressor with air treatment system, compressor control system,

21. system of external cameras,

22. bateries,

23. halogen and LED headlights,

24. multi-control sockets,

25. SHP electromagnets,

26. GPS antenna,

27. radio control antenna,

28. sandbox,

29. main air tanks.

Fig. 13. Arrangement of the main components on the 19D locomotive 
The 19D locomotive, after modernization, had a maximum power of $1350 \mathrm{~kW}$ at the wheel circumference, a tractive force of $122 \mathrm{kN}$ and a tractive starting force of $455 \mathrm{kN}$. The vehicle could travel with a continuous speed of $40 \mathrm{~km} / \mathrm{h}$. Additionally, the designers made sure that the locomotive could be operated with multiple traction as an option. A summary of the basic locomotive parameters before and after the modernization was presented in Table 1.

The modernization of the 19D locomotive in terms of the drive system was planned in an effort to meet the requirements of the Stage IIIB exhaust emission norms, according to Directive 2004/26/EC of the European Parliament, in the scope of limiting the exhaust emission of gaseous pollutants and particulates [9]. The modern MTU 12V4000R84 engine installed in the locomotive meets the above-mentioned limits. The worn-out PD1M unit, which was replaced from the vehicle, met the exhaust emission limits specified in the ORE B13 standard, which was in force until 1981. The presented test was carried out in real operating conditions (Fig. 14). There is a large range of variability of the parameters (in terms of rotational speed and load). The conditions have a negative impact on the emission of pollutants, as presented in the paper [23]. The obtained results were compared with the standards for which tests are performed under steady engine operating conditions.

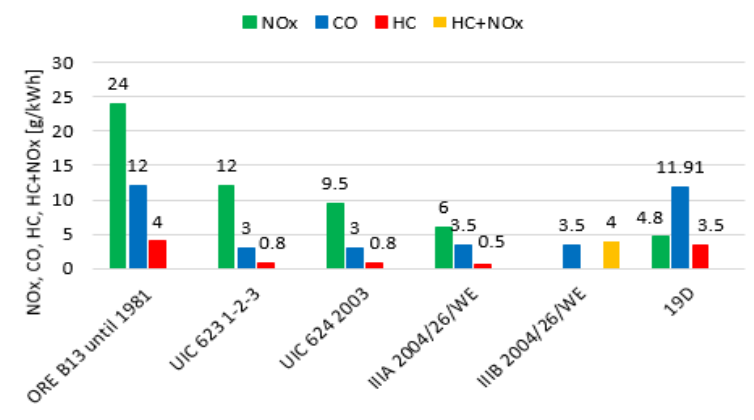

Fig. 14. Example of exhaust emission for a diesel engine of the locomotive SM48 (19D)

Table 1. Basic locomotive parameters before and after modernization

\begin{tabular}{|c|c|c|c|c|c|}
\hline \multirow{2}{*}{ No. } & \multirow{2}{*}{\multicolumn{2}{|c|}{ Device, parameter }} & \multirow{2}{*}{ Unit } & \multicolumn{2}{|c|}{ Value } \\
\hline & & & & Before modernization & After modernizaion \\
\hline 1. & \multicolumn{2}{|c|}{ Base locomotive manufacturer } & - & \multicolumn{2}{|c|}{ USSR MZ Briańsk } \\
\hline 2. & \multicolumn{2}{|c|}{ Type } & - & TEM2 & 19D \\
\hline 3. & \multicolumn{2}{|c|}{ Service weight of the locomotive } & {$[\mathrm{Mg}]$} & \multicolumn{2}{|c|}{$\frac{1}{118^{-3 \%}}$} \\
\hline 4. & & & {$[\mathrm{~km} / \mathrm{h}]$} & \multicolumn{2}{|c|}{100} \\
\hline \multirow{2}{*}{5.} & \multirow{2}{*}{\multicolumn{2}{|c|}{ Transmission type }} & \multirow{2}{*}{-} & electric & electric \\
\hline & & & & DC-DC & AC-DC \\
\hline \multirow{2}{*}{6.} & \multirow{2}{*}{ Brake } & main & \multirow{2}{*}{ - } & Matrosow & $\mathrm{MH}$ \\
\hline & & parking & & & spring \\
\hline 7. & Traffic s & devices & - & none & SHP, CA, RS \\
\hline \multirow{7}{*}{8.} & \multirow{7}{*}{ Combustion engine } & manufacturer & - & USSR & MTU \\
\hline & & type & - & PD1M & 12V 4000 R84 \\
\hline & & rated power & {$[\mathrm{kW}]$} & 883 & 1800 \\
\hline & & engine speed & [rpm] & 750 & 1800 \\
\hline & & exhaust emissions & - & No data & $\begin{array}{c}\text { EU 26/2004 } \\
\text { stage III B }\end{array}$ \\
\hline & & fuel consumption & $\mathrm{g} / \mathrm{kWh}$ & 229 & $202^{+5 \%}$ \\
\hline & & lubricant consumption & $\mathrm{g} / \mathrm{kWh}$ & No data & $0.2 \%$ of the fuel consumed \\
\hline \multirow{3}{*}{9.} & \multirow{3}{*}{ Main generator } & manufacturer & \multirow{5}{*}{$\begin{array}{c}{[\mathrm{kW}]} \\
- \\
{[\mathrm{kW}]}\end{array}$} & \multirow{3}{*}{$\begin{array}{c}\text { USSR } \\
\text { GP-300BU2 } \\
780\end{array}$} & \multirow{3}{*}{$\begin{array}{c}\text { JENOPTIK } \\
\text { SDV 95.50-12 } \\
1800\end{array}$} \\
\hline & & type & & & \\
\hline & & $\begin{array}{l}\text { continuous } \\
\text { rated power }\end{array}$ & & & \\
\hline \multirow[b]{2}{*}{10.} & \multirow[b]{2}{*}{ Auxiliary generator } & manufacturer & & USSR & JENOPTIK \\
\hline & & $\begin{array}{l}\text { continuous } \\
\text { rated power }\end{array}$ & & $\begin{array}{c}\text { MWG-25/IIU2 } \\
5.75\end{array}$ & $\begin{array}{c}\text { SDV } 60.26-12 \\
120\end{array}$ \\
\hline \multirow[b]{2}{*}{11.} & \multirow[b]{2}{*}{ Traction motors } & type & \multirow{2}{*}{$\begin{array}{l}- \\
\mathrm{kW}\end{array}$} & \multicolumn{2}{|c|}{ ED 118 AU2 } \\
\hline & & $\begin{array}{l}\text { continuous } \\
\text { rated power }\end{array}$ & & 105 & $\sim 245$ \\
\hline 12. & Control & t voltage & {$[\mathrm{V}]$} & 75 & 24 \\
\hline 13. & Cont & stem & - & electric & digital \\
\hline & & type, supply & & piston, & screw, \\
\hline 14. & Air compressor & air output & $\mathrm{m}^{3} / \mathrm{min}$ & $\begin{array}{c}\text { from the crankshaft } \\
4.6\end{array}$ & $\begin{array}{c}\text { electric motor, } 3 \times 400 \mathrm{~V}_{\mathrm{AC}} \text {, } \\
22 \mathrm{~kW} \\
2.9\end{array}$ \\
\hline 15. & Radiat & n drive & - & Cardan shaft & $\begin{array}{c}\text { hydrostatic - stepless speed } \\
\text { control }\end{array}$ \\
\hline 16. & traction $\mathrm{m}$ & fans drive & - & belt transmission & electric motor, $3 \times 400 \mathrm{~V}_{\mathrm{AC}}$ \\
\hline 17. & & cab & - & & $\begin{array}{c}\text { new equipment that meets } \\
\text { the current requirements in } \\
\text { terms of ergonomics and } \\
\text { work safety }\end{array}$ \\
\hline 18. & $\begin{array}{r}\text { Fixed fire extinguishir } \\
\mathrm{p} \\
\end{array}$ & $\begin{array}{l}\text { iice in the engine com- } \\
\text { nt }\end{array}$ & - & none & aerosol generator \\
\hline
\end{tabular}




\section{Conclusions}

The 19D locomotive project is an example of how the $3 \mathrm{D}$ environment can be used in design and construction works. By creating the locomotive model, and performing analyzes and simulations the work was significantly accelerated, which contributed to reducing the overall costs of vehicle modernization. In the described locomotive, modern assemblies and systems were used, which increased the reliability and extended the maintenance intervals.

The main aim of the article was to present the activities related to the modernization of the SM48 (TEM2) locomotive, in particular the equipment used and the work carried out on the vehicle drive system. The modernized locomotive was characterized by low environmental impact. The use of the modern 12V4000R84 internal combustion engine manufactured by MTU, which meets the Stage IIIB emission norms, has significantly reduced the generated exhaust emissions. The drive unit was characterized by lower specific fuel consumption - $202 \mathrm{~g} / \mathrm{kWh}$ - and consequently higher efficiency. In addition, the new engine has twice the power of the previous one. As a result of the modernization, the 19D locomotive is the locomotive with the highest rated power of this type in Poland. The vehicle was put into use by carriers, where it currently performs the most difficult maneuvering and shunting works and is used to move heavy freight trains.

To sum up, given the current technical condition of the railway infrastructure and rolling stock, as well as its average age, the modernization of rail vehicles in Poland is a procedure necessary to improve the technical level, reliability and operating safety of the existing rolling stock. In addition, this type of activity increases the drivers work comfort as well as making the vehicle maintenance easier. For this reason, the purchase of new units, along with renovation and modernization of older rolling stock should be a permanent part of the activity of the railway carriers in Poland.

\section{Acknowledgements}

Applied Research Program 3 No PBS3/B6/33/2015 titled: „Platform of modernized combustion 6-axle locomotives meeting the requirements of European Union with using locomotives operated in the country”.

\section{Nomenclature}

$\begin{array}{llll}\text { CFD } & \text { Computational Fluid Dynamics } & \text { SHP } & \text { Automatic braking system } \\ \text { DPF } & \text { Diesel Particle Filter } & \text { REBS } & \text { A manufacturer in Germany } \\ \text { Stage IIIB } & \text { European Non-Road Emission Standard } & \text { EGR } & \text { Exhaust Gas Recirculation } \\ \text { MTU } & \begin{array}{l}\text { A manufacturer of internal combustion } \\ \text { engines }\end{array} & \text { LT/HT } & \text { Low Temperature/High Temperature } \\ & \text { POM } & \text { Power Output Module }\end{array}$

ORE B13 A regulation of emission limits

\section{Bibliography}

[1] 2019 in passenger and freight transport - Summary of Office of Rail Transport. Office of Rail Transport. 2020.

[2] ANDRZEJEWSKI, M., GALLAS, D., DASZKIEWICZ, P. et al. The latest technical solutions in rail vehicles drives. MATEC Web of Conferences. 2017, 118. https://doi.org/10.1051/matecconf/201711800015

[3] BAUMGARTNER, C., WEIß, T., ZITZLER, G. et al. New MTU series 4000 rail engine fulfilling most ambitious emission regulation. Heavy-Duty-, On- und Off-Highway-Motoren 2017. 2018, 137-149. https://doi.org/10.1007/978-3-65821029-8_8

[4] BIELACZYC, P., MERKISZ, J., PIELECHA, J. et al. RDEcompliant PEMS testing of a gasoline Euro 6d-TEMP passenger car at two ambient temperatures with a focus on the cold start effect. SAE Technical Paper 2020-01-0379. 2020. https://doi.org/10.4271/2020-01-0379

[5] CARVAlHAES, B.B., ROSA, R.A., D'AGOSTO, M.A. et al. A method to measure the eco-efficiency of diesel locomotive. Transportation Research Part D: Transport and Environment. 2017, 51, 29-42. https://doi.org/10.1016/j.trd.2016.11.031

[6] CICHY, R. Authorization of vehicles for placing in service after modernization and renewal. European and national requirements. Pojazdy Szynowe. 2017, 1, 31-43.

[7] DALlMANN, T., MENON, A. Technology pathways for diesel engines used in non-road vehicles and equipment. White Paper, The International Council on Clean Transportation. 2016.

[8] DASZKIEWICZ, P., RYMANIAK, Ł., KAMIŃSKA, M. Issues of emission evaluation of road-rail vehicles in the as- pect of current type approval regulations. Combustion Engines. 2019, 178(3), 269-273. https://doi.org/10.19206/CE2019-347

[9] Directive 2004/ 26/EC of the European Parliament and of the Council of 21 April 2004 amending Directive 97/68/EC on the approximation of the laws of the Member States relating to measures against the emission of gaseous and particulate pollutants from internal combustion engines to be installed in non-road mobile machinery

[10] KAPETANOVIĆ, M., VAN OORT, N., NÚÑEZ, A. et al. Sustainability of railway passenger services - a review of aspects, issues, contributions and challenges of life cycle emissions. 8th International Conference on Railway Operations Modelling and Analysis (ICROMA). 2019.

[11] LIUDVINAVIČIUS, L., DAILYDKA, S. The aspects of modernization of diesel-electric locomotives and platform for transportation of railway switches in Lithuanian Railways. In: Stadkowski A. (eds) Rail Transport-Systems Approach. 2017, 87. https://doi.org/10.1007/978-3-319-51502-1_4

[12] LIUDVINAVIČIUS, L., JASTREMSKAS, V. Modernization of diesel-electric locomotive 2M62 and TEP-70 locomotives with respect to electrical subsystem. Procedia Engineering. 2017, 187, 272-280. https://doi.org/10.1016/j.proeng.2017.04.375

[13] MAŠKOVÁ, K. Economy of railway transport from the point of view of the client. Master's Thesis, Czech Technical University, Prague 2019.

[14] MIKLASZ, R., MILECKI, S. Modernization of the TEM2 locomotive bogies with the aim of reducing operational con- 
tamination of the environment. Pojazdy Szynowe. 2017, 1, 44-52.

[15] Office of Rail Transport. Internet website: https://utk.gov.pl/

[16] PIELECHA, I., MERKISZ, J., ANDRZEJEWSKI, M. et al. Ultracapacitors and fuel cells in rail vehicle drive systems. Pojazdy Szynowe. 2019, 2, 9-19.

[17] PIELECHA, J., ANDRYCH-ZALEWSKA, M., SKOBIEJ, $\mathrm{K}$. The impact of using an in-cylinder catalyst on the exhaust gas emission in real driving conditions tests of a diesel engine. IOP Conference Series: Materials Science and Engineering. 2018, 421(4). https://doi.org/10.1088/1757-899X/421/4/042064

[18] Progress Rail Services: EMD Tier 4 (PM) Aftertreatment Upgrade on a Line Haul Locomotive. Final Report 20102012.

[19] Resolution No. 162/2015 of the Council of Ministers of September 15, 2015 on the establishment of the National Railway Program until 2023. 2015.

[20] RJABTŠIKOV, V., RASSÕLKIN, A., VAIMANN, T. et al. Possibilities of changing the transport characteristics of the TEP70 locomotive. 27th International Workshop on Electric Drives (IWED2020). 2020.

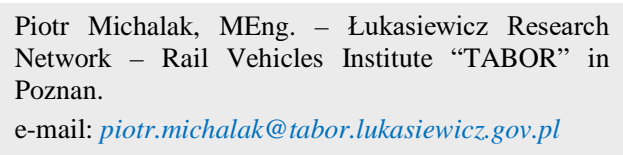

Włodzimierz Stawecki, Ph.D. - Łukasiewicz Research Network - Rail Vehicles Institute “TABOR” in Poznan.

e-mail:

wlodzimierz.stawecki@tabor.lukasiewicz.gov.pl
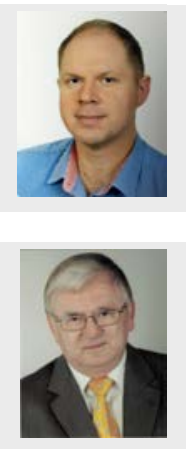

Paweł Daszkiewicz, DEng. - Łukasiewicz Research Network - Rail Vehicles Institute “TABOR" in Poznan.

e-mail:pawel.daszkiewicz@tabor.lukasiewicz.gov.pl

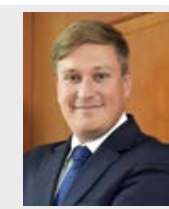

https://doi.org/10.1109/IWED48848.2020.9069576

[21] Rolling stock potential, Trends and forecasts. Office of Rail Transport. 2019.

[22] RYABKO, E., RYABKO, K. Effectiveness of diesellocomotive shunter modernization and ways for its definition. Bulletin of Bryansk State Technical University. 2020, 5(90), 23-31. https://doi.org/10.30987/1999-8775-2020-5-23-31

[23] RYMANIAK, Ł. Comparison of the combustion engine operating parameters and the ecological indicators of an urban bus in dynamic type approval tests and in actual operating conditions. MATEC Web of Conferences. 2017, 118. https://doi.org/10.1051/matecconf/201711800009

[24] RYMANIAK, Ł., FUĆ, P., LIJEWSKI, P. et al. Evaluating the environmental costs in Poland of city buses meeting the Euro VI norm based on tests in real operating conditions. Archives of Transport. 2019, 52(4), 109-115. https://doi.org/10.5604/01.3001.0014.0212

[25] Statistics Poland. Internet website https://stat.gov.pl/en/

[26] The rolling stock of freight carriers - current state and plans until 2023. Office of Rail Transport. 2018.

[27] Transport Sustainable Development Strategy until 2030. Polish Council of Ministers. 2019.

Prof. Jerzy Merkisz, DSc., DEng. - Faculty of Civil and Transport Engineering, Poznan University of Technology.

e-mail: jerzy.merkisz@put.poznan.pl

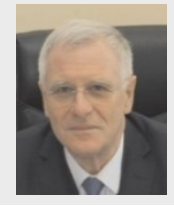

Maciej Andrzejewski, DEng. - Łukasiewicz Research Network - Rail Vehicles Institute "TABOR" in Poznan.

e-mail:

maciej.andrzejewski@tabor.lukasiewicz.gov.pl

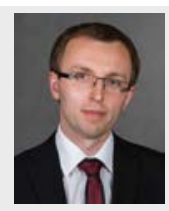

